\title{
TREATMENT OF SWINE WASTEWATER USING ANAEROBIC FILTERS WITH DIFFERENT TYPES OF SUPPORT MEDIA
}

\author{
TRATAMENTO DE ÁGUAS RESIDUÁRIAS DE SUINOCULTURA EM \\ FILTROS ANAERÓBIOS COM DIFERENTES TIPOS DE MEIO SUPORTE
}

\section{Eduardo France $\mathrm{OZA}^{1^{*}}$; Paola Alfonsa Vieira LO MONACO Ismail Ramalho HADDAD ${ }^{2}$; Millena Monteiro dos SANTOS ${ }^{3}$; Debora Moro SOELA ${ }^{3}$; Gustavo Haddad Souza VIEIRA ${ }^{2}$}

1. Estudante de mestrado, Universidade Estadual do Norte Fluminense Darcy Ribeiro, UENF, Campos de Goytacazes, RJ, Brasil, eduardo.franceoza@hotmail.com; 2. Docente, Instituto Federal do Espírito Santo, Ifes, campus Santa Teresa, ES, Brasil. 3. Estudante de mestrado, Universidade Federal do Espírito Santo, UFES, campus São Mateus, ES, Brasil

\begin{abstract}
Research using anaerobic filters as alternative materials to gravel becomes fundamental, especially if they are low cost, accessible and have high efficiency in the treatment of swine wastewater. This study aimed to evaluate the efficiency of anaerobic filters with different types of support media, as an alternative to gravel, in the treatment of swine wastewater. We carried out the experiment in a completely randomized design. The treatments were composed of anaerobic filters with four different media (gravel, bamboo, luffa sponge and foam), three replications in a time-repeated measurements scheme $(0,60,120,180$ and 240 days post-filter establishment). To determine the efficiency of removal by the filters, we performed analysis of turbidity, total solids, biochemical oxygen demand (bod), total $\mathrm{n}$ and total $\mathrm{p}$ in the affluent to and effluent from the filters. Among the alternative media, bamboo presented an efficiency of removal of the evaluated attributes similar and, in most cases, superior to gravel. From 60 to 180 days of filter operation, the luffa sponge remained with high turbidity and total solids removals, with the greatest decrease at 240 days of operation. After two months of filter operation, the alternative support media exhibited bod and total $\mathrm{n}$ removal similar to that of gravel. At 240 days of operation, the filters containing luffa sponge and bamboo showed the highest total p removal.
\end{abstract}

KEYWORDS: Wastewater. Secondary treatment. Removal efficiency.

\section{INTRODUCTION}

Swine farming is an activity that, on a commercial scale, has expanded greatly in the last few decades due to increase in the demand for meat and pork products, being an important activity from a social, economic and, especially, in maintaining the people in rural areas (MATOS et al., 2009).

The development of swine farming raises major concerns about the amount of waste produced, which is highly polluting, especially when released into water bodies without prior treatment. Matos et al. (2010) emphasize that, in addition to surface and groundwater pollution, inappropriate application of these wastes to the soil can lead to salinization, pollution and structure damage.

As environmental legislation establishes standards for the discharge of effluents into water bodies, treatment of the wastewater is necessary if this is its intended final destination.

There are several processes for effluent treatment and/or use, which mostly are highly efficient, however, they require large investments.
On the other hand, small family farmers, as is the case of most rural properties in the Espírito Santo state, Brazil, lack resources, technical assistance and are unable to employ sophisticated methods for treating the waste generated on their farms.

Among the simple solutions, proposals for the treatment of wastewater rich in organic material, as is the case of those coming from smaller swine farms, we highlight the upward flow anaerobic filter. According to (SOUZA et al., 2010), the anaerobic filters can be defined as biological reactors filled with some material with a good adhesion surface, both immobile and inert. They are systems that facilitate the proliferation of anaerobic microorganisms, which form a thin layer, called a biofilm or sludge, involving filler which acts as an absorbent. Tonetti et al. (2011) reinforce that anaerobic filters are a low-cost option in both the construction and operational aspects, removing approximately $70 \%$ of organic matter and producing a small amount of sludge.

One of the impediments to the adoption of real-scale anaerobic filters refers to the cost of the filler material as a support media, and it is possible 
to achieve the same magnitude of the filter construction (TONETTI et al., 2011). In this sense, research has been carried out using low cost materials and those with high availability as media for anaerobic filters, such as building waste (CAMPOS et al., 2008), bamboo rings (TONETTI et al., 2011; 2012), blast furnace slag (FIA et al., 2010), luffa sponge (FERNANDES et al., 2015), and plastic corrugated conduit rings (ARAÚJO et al., 2016). With the exception of Fia et al. (2010), which used coffee wastewater, all the authors mentioned using anaerobic filters in the domestic sewage treatment.

Research using alternative materials to gravel becomes essential, especially if they are lowcost, accessible and provide high efficiency in wastewater treatment. Thus, this study is justified due to the lack of efficiency data relating to the use of these materials in swine wastewater treatment.
Thus, this study aimed to evaluate the efficiency of anaerobic filters with different types of support media, as an alternative to gravel, in swine wastewater treatment.

\section{CONTENTS}

We installed and conducted the experiment during the period December 2016 to July 2017 at the Instituto Federal do Espírito Santo, Santa Teresa Campus, Brazil.

The experimental workbench consisted of 12 upward flow anaerobic filters made of polyvinylchloride (PVC), each with a capacity of $5.1 \mathrm{~L}$, completely filled with the relevant media support. The volume of void for each media support (Table 1) was determined to calculate the flow rate of each filter.

Table 1. Volume of void for each filter and its respective flow rate.

\begin{tabular}{lcl}
\hline Media support & Volume of void & Flow rate \\
\hline Gravel & $60 \%$ & $5.8 \mathrm{~mL} \mathrm{~min}^{-1}$ \\
Bamboo & $75 \%$ & $6.0 \mathrm{~mL} \mathrm{~min}$ \\
Luffa sponge & $82 \%$ & $6.9 \mathrm{~mL} \mathrm{~min}^{-1}$ \\
Foam & $76 \%$ & $6.4 \mathrm{~mL} \mathrm{~min}^{-1}$ \\
\hline
\end{tabular}

The gravel used in the experiment was purchased from a building material store. It was classified as No. 4, with a diameter of 50 to $76 \mathrm{~mm}$, which had been washed and sieved to provide uniform granulometry. The bamboo rings, obtained from the cut of cultivated clumps on campus, had average dimensions of $3 \mathrm{~cm}$ in height and $2 \mathrm{~cm}$ in diameter. The cuts of luffa sponge (Luffa cylindrica) were, on average, $5 \mathrm{~cm}$ in height and $12 \mathrm{~cm}$ in diameter and were acquired from family farms belonging to the Santa Teresa Agroecology Association of Espírito Santo state, Brazil. The polyurethane foam cubes were obtained from discarded mattresses with density of $33 \mathrm{~kg} \mathrm{~m}^{-3}$ (D 33 ), and trimmed to a size of approximately $3 \times 3 \times$ $3 \mathrm{~cm}$ (height $\mathrm{x}$ length $\mathrm{x}$ width). The different types of support media were dried in the shade and protected against insects and pollution.

With the dimensions established for this study, each anaerobic filter has the capacity to treat approximately $3.6 \mathrm{~L}$ of swine wastewater with $12 \mathrm{~h}$ of hydraulic detention time (HDT). Thus, the daily treatment capacity was $7.2 \mathrm{~L}$. If the average daily production of wastewater per animal of $8.6 \mathrm{~L}$ (comprised of feces and urine) is considered, each filter is capable of treating the daily effluent produced by 0.84 animals.
The filters operated with upward flow in the treatment of wastewater from the swine farm from Santa Teresa campus. The effluent was stored in a 500-L capacity fiberglass tank installed in a structure $2 \mathrm{~m}$ above the filters, causing them to feed by gravity. The retention time of the effluent in the filter was $12 \mathrm{~h}$. The output flow was measured daily and adjusted to remain at the values established by the calculation of void volume. Sampling of crude and treated effluent was performed every 15 days during the 8-month experimental period.

The crude and treated effluent was analyzed for $\mathrm{pH}$, turbidity, total solids (TS), suspended solids (SS), total nitrogen, total phosphorus and biochemical oxygen demand (BOD). The analysis was performed at the Water Quality Laboratory of the Ifes - Santa Teresa campus, following the methodology described in Matos (2015). Due to laboratory problems, total $\mathrm{P}$ removal efficiency analysis was only initiated 150 days after the start of the filter operation and analysis of BOD, total $\mathrm{N}$ and total $\mathrm{P}$ was not performed at 240 days of filter operation.

In order to determine the filter removal efficiency (E), the values of the influent and effluent concentrations of the filters were calculated according to Equation 1. 
$\mathrm{E}=\frac{\left(\mathrm{C}_{\mathrm{af}}-\mathrm{C}_{\mathrm{ef}}\right)}{\mathrm{C}_{\mathrm{af}}} \times 100$

Where:

$\mathrm{C}_{\mathrm{af}}=$ affluent concentration, $\mathrm{mg} \mathrm{L}^{-1}$;

$\mathrm{C}_{\mathrm{ef}}=$ effluent concentration, $\mathrm{mg} \mathrm{L}^{-1}$;

$\mathrm{E}=$ removal efficiency, $\%$.
The treated effluent presented values close to the optimum range for the performance of methaneproducing microorganisms, recommended by (CHERNICHARO, 1997), which is 6 to 8.3. The other effluent attributes are presented in Table 2.

Table 2. Maximum, average and minimum values of electrical conductivity (CE); turbidity; hydrogenation potential ( $\mathrm{pH})$; biochemical oxygen demand (BOD); total nitrogen; total phosphorus; total solids (TS) and suspended solids (SS) from raw swine wastewater.

\begin{tabular}{|c|c|c|c|c|c|c|c|c|}
\hline \multirow[b]{2}{*}{$\begin{array}{l}\text { Evaluation } \\
\text { period (days) }\end{array}$} & $\mathrm{EC}$ & Turbidity & \multirow{2}{*}{$\mathrm{pH}$} & \multirow[t]{2}{*}{ BOD } & \multirow[t]{2}{*}{ Total N } & \multirow{2}{*}{$\begin{array}{l}\text { Total P } \\
\left(\mathrm{mg} \mathrm{L}^{-1}\right)\end{array}$} & \multirow[t]{2}{*}{$\mathrm{TS}$} & \multirow[t]{2}{*}{ SS } \\
\hline & $\left(\mathrm{dS} \mathrm{m} \mathrm{m}^{-1}\right)$ & (NTU) & & & & & & \\
\hline 0 & 4.67 & 443 & 8.5 & 343.5 & 4900 & 31.4 & 1596.7 & 703.3 \\
\hline 60 & 4.33 & 238 & 8.1 & 229.3 & 6160 & 36.8 & 2583.3 & 1368.8 \\
\hline 120 & 2.98 & 225 & 8.0 & 232.2 & 7700 & 43.2 & 3873.3 & 1323.2 \\
\hline 180 & 4.59 & 320 & 8.4 & 374.8 & 5880 & 56.2 & 3910.0 & 1196.3 \\
\hline 240 & 4.97 & 272 & 8.2 & 231.1 & 8980 & 53.5 & 2693.3 & 984.3 \\
\hline
\end{tabular}

The low BOD values for swine wastewater are explained by the stalls scraping before their washing, which considerably reduces the organic load of the generated effluent.

The experiment was conducted as a completely randomized design (CRD) in a split-plot scheme, using the technique of variance analysis for repeated measures over time. The treatments allocated to the plots comprised four different types of biological filters (gravel, bamboo, luffa and foam), with three replicates, and those distributed in the subplots comprised different evaluation periods $(0,60,120,180$ and 240 days post-implementation of the filters). In order to analyze the intra-subject factors (evaluation periods within the filter factor), Mauchly's test of stress was performed to verify if the covariance matrix of the errors would satisfy the condition of compound symmetry (similarity of variance and null correlations). If sphericity did not occur $(P<0.05)$, the degrees of freedom of the factors in the subplots (evaluation periods and the interaction between them and the filter factor) were rectified. Before the analysis of variance, each variable was tested for homogeneity of variances (Levene's test) and normality of the standardized residues (Shapiro-Wilk's test). After effects for the isolated factors or for the interaction (Filter $\mathrm{x}$ Period) were verified, effect comparisons were performed by means of multiple comparisons using the Sidak test. The SPSS Statístics 20 program was used for statistical procedures.
In general, it can be seen that, with the exception of the 120-day period, the alternative media presented turbidity removal efficiencies that were similar to or significantly greater than gravel $(\mathrm{P}<0.01)$ during the operation periods evaluated (Table 3). As turbidity is a variable correlated with the presence of suspended solids, high removal efficiency can be attributed to the higher pore volume values of the alternative materials compared to the gravel (Table 1). According to MiddleBrooks (1988), the physical retention of solids in filters occurs mainly in the voids between the media support, due to the accumulation of material in the filter; this mechanism is accentuated in reactors with a high specific surface area of the media support.

The removal efficiency (\%) of turbidity and total solids (TS) for the different types of media support and evaluation periods are presented in Table 3.

As shown in Table 3, there was no statistically significant difference $(\mathrm{P}<0.01)$ between the different types of media support at the first evaluation period ( 0 days), with turbidity removal efficiencies of around $70 \%$. 
Table 3. Average removal efficiency (\%) of turbidity (T) and total solids (TS) for different types of media support and evaluation periods.

\begin{tabular}{|c|c|c|c|c|c|c|c|c|c|}
\hline \multirow{2}{*}{ Variable } & \multirow{2}{*}{$\begin{array}{l}\text { Media } \\
\text { support }\end{array}$} & \multicolumn{5}{|c|}{ Evaluation period, EP (days) } & \multicolumn{3}{|c|}{$P$ values } \\
\hline & & 0 & 60 & 120 & 180 & 240 & Filter & EP & Filter*EP \\
\hline \multirow{4}{*}{$\mathrm{T}$} & Gravel & $75.25 \mathrm{Aab}$ & $55.13 \mathrm{Cd}$ & $87.46 \mathrm{Aa}$ & $66.35 \mathrm{Bbc}$ & $57.60 \mathrm{BCcd}$ & \multirow{4}{*}{0.009} & \multirow{4}{*}{0.000} & \multirow{4}{*}{0.004} \\
\hline & Bamboo & $70.93 \mathrm{Ab}$ & $74.16 \mathrm{Bb}$ & $90.85 \mathrm{Aa}$ & $83.38 \mathrm{Aab}$ & $77.56 \mathrm{Ab}$ & & & \\
\hline & Luffa & $\begin{array}{c}69.91 \mathrm{Aa} \\
72.40\end{array}$ & $75.86 \mathrm{Aa}$ & $88.13 \mathrm{Aa}$ & $89.91 \mathrm{Aa}$ & $50.98 \mathrm{Cb}$ & & & \\
\hline & Foam & $\mathrm{Abc}$ & $73.09 \mathrm{Bb}$ & $72.31 \mathrm{Bbc}$ & $81.58 \mathrm{Aa}$ & $64.38 \mathrm{Bc}$ & & & \\
\hline \multirow{4}{*}{ TS } & Gravel & $31.87 \mathrm{Bd}$ & 64.39 Aab & $47.25 \mathrm{Ac}$ & $31.07 \mathrm{Ad}$ & $83.27 \mathrm{Aa}$ & \multirow{4}{*}{0.001} & \multirow{4}{*}{0.000} & \multirow{4}{*}{0.002} \\
\hline & Bamboo & $15.36 \mathrm{Dd}$ & $62.93 \mathrm{Ab}$ & $52.36 \mathrm{Abc}$ & $41.85 \mathrm{Ac}$ & $82.83 \mathrm{Aa}$ & & & \\
\hline & Luffa & $\begin{array}{c}18.15 \mathrm{Cc} \\
40.85\end{array}$ & $64.66 \mathrm{Aa}$ & $42.82 \mathrm{Ab}$ & $35.16 \mathrm{Ab}$ & $45.46 \mathrm{Bb}$ & & & \\
\hline & Foam & Acd & $64.99 \mathrm{Ab}$ & $49.45 \mathrm{Ac}$ & $35.88 \mathrm{Ad}$ & $85.31 \mathrm{Aa}$ & & & \\
\hline
\end{tabular}

Average values followed by the same capital letters, in the columns, and lowercase, in the rows, are equal to each other according to the Sidak test. $* \mathrm{P}=0.05$

Among the different types of support material, we observed that luffa showed the highest efficiency at 60 days of operation, and there was no statistical difference $(\mathrm{P}<0.01)$ from the beginning up to 180 days (Table 3). This media support presented high efficiency (69.91 to $89.91 \%$ ) over the evaluation periods, which can be attributed to the higher pore volume (Table 1) and to the larger specific surface area, assisting in the removal mechanisms, mainly in biological assimilation and physical retention. At 240 days of operation, there was a decrease in the efficiency of turbidity removal which is probably be associated with the degradability of its structure, allowing the opening of preferential channels and reducing the restriction to the flow. The degradability of its structure can be related to the concentration of salts in the wastewater, demonstrated by the high value of electrical conductivity (Table 2). Chanakya e Khuntia (2014), evaluating the degradation of another plant species (Luffa acutangula), very similar to the one used in this study (Luffa cylindrica), verified the material degradation of 93.5\% at the end of the 408-day period of study. It should be noted that, even with the lowest efficiency at 240 days, luffa did not differ significantly ( $P$ $<0.01$ ) from gravel (Table 3).

At 120 days, filters composed of bamboo and luffa presented high turbidity removal efficiencies, but not significantly different $(\mathrm{P}<0.01)$ from gravel. At 180 days of operation, the filters composed of bamboo, luffa and foam showed turbidity removal efficiencies that were significantly higher $(\mathrm{P}<0.01)$ than the gravel (Table 3$)$.

At 240 days of operation, the filters composed of bamboo rings provided the highest efficiency among all the materials evaluated, indicating that its structure, in the form of rings arranged along the filters, has high filtering action, as observed by Souza et al. (2010). In addition, the higher efficiency of bamboo filters at 240 days of operation may be associated with greater adaptation of the biological film in this support material, in addition to the high resistance to long periods of use in anaerobic filters, as suggested by Tonetti et al. (2011), when compared to the luffa and the foam. The average turbidity removal efficiency of the bamboo ring filters $(79.4 \%)$ was similar to that found by Souza et al. (2010), who reported efficiency of $82.4 \%$ in the removal of this variable in filters containing bamboo rings, with the same duration of operation; however, this study involved treating domestic effluent.

In the case of total solids (TS), it was shown that, at the first evaluation point ( 0 days), all support materials were significantly different $(\mathrm{P}<0.01)$ from each other, presenting low removal efficiencies (15.36 to $40.85 \%)$. This result was anticipated due to the incipient, or even absent, formation of the bacterial film in the supported materials. Tonetti et al. (2011), when evaluating anaerobic filters with bamboo filling in the domestic effluent treatment with HDT of $9 \mathrm{~h}$, demonstrated that formation of the bacterial biofilm took up to several months.

At 60 days of operation, there was an increase in TS removal efficiency (around 64\%) with all media and there were no statistically significant differences between them. This result may be associated with the evolution of the bacterial film, which contributes to the wastewater TS removal efficiency. 
The maximum, average and minimum temperature data over the evaluation period are shown in Figure 1.

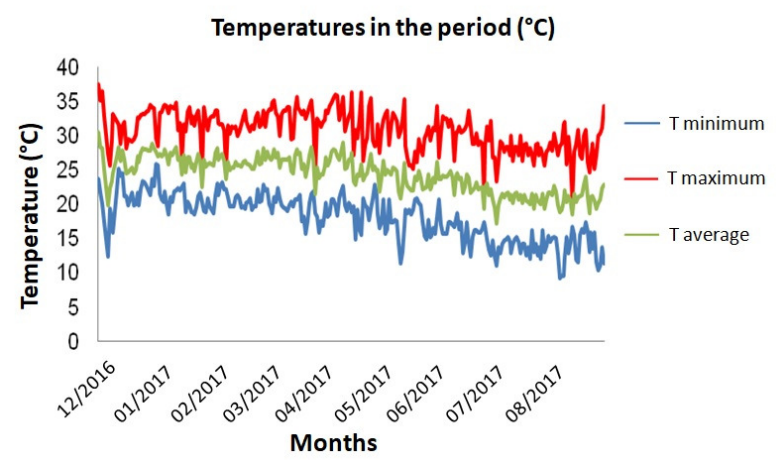

Figure 1. Maximum, average and minimum daily temperatures throughout the evaluation period.

At 120 and 180 days of operation, a reduction in removal efficiency (around 47\%) occurred with all filters and there was no statistically significant difference between them. This reduction may be associated with the high concentration of TS present in swine wastewater (Table 2) which tends to inhibit the hydrolysis by microorganisms, causing destabilization of the medium, as suggested by Kim et al. (2009). In addition, stochastic factors, such as thermal amplitude that occurred in the period (Figure 1), may have interfered in microbial colonies. Chernicharo (2007) points out that microorganisms do not have mechanisms to control their internal temperature, which is determined by the ambient temperature. According to Appels et al. (2008), the efficiency of anaerobic filters can be compromised by temperature oscillation due to the sensitivity of most microorganisms, since they have little tolerance to temperature variations above $2^{\circ} \mathrm{C}$ daily. In addition, the same authors point out that high temperatures also promote an increase in the partial pressure of hydrogen, increasing the concentration of free ammonia which tends to inhibit the anaerobic processes.

At the end of the evaluation period (240 days), in addition to the reduction in affluent TS concentration (Table 2), thermal amplitude decreased with the arrival of winter (Figure 1), the coldest season of the year, causing smaller oscillation between minimum and maximum temperatures during the day and enabling filters to increase TS removal efficiencies.

High TS removal efficiencies were obtained with filters containing foam $(85.36 \%)$, gravel $(83.27 \%)$ and bamboo $(82.83 \%)$ at 240 days of evaluation, with no significant differences $(\mathrm{P}<0.05)$ between these materials (Table 3 ). Those filters containing cuts of luffa had lower removal efficiency $(45.46 \%)$, differing from the others. This finding may be related to the degradability of its structure which allowed the opening of preferential channels, reducing the restriction to flow, similar to the effect on turbidity removal. Fernandes et al. (2015), when evaluating the efficiency of filters containing luffa as a media support in domestic sewage treatment, reported that, as luffa is an organic material, it is easily degraded and can contribute to the low TS and turbidity efficiencies, corroborating the results found in this study.

The high efficiency obtained in the TS removal by the filter containing foam $(85.36 \%)$ can be attributed to the internal structure of this media support. According to Zaiat et al. (1994), the structure of foam cubes is formed by internal microgaleries which favor the filtering of solids and microorganism proliferation in these gallery walls; this increases contact of the microbial biofilm with the wastewater.

According to Figure 2a, a low BOD removal efficiency is observed at up to 40 days of operation with all anaerobic filters. This finding was anticipated due to the time required for the formation of the biological film. In addition, the $\mathrm{pH}$ during this period was above 8.3 (Table 2). According to Chernicharo (1997), $\mathrm{pH}$ values below 6.0 and above 8.3 should be avoided as they may completely inhibit methane-forming bacteria, which may lead to a decrease in removal efficiency of methane, which in turn may cause decreased removal efficiency of organic matter present in the sewage.

From 60 days of operation, the filters were more efficient in BOD removal and operationally stable, indicating that the system had reached dynamic equilibrium, that is, there was a greater capacity for biomass immobilization and, consequently, greater assimilation of organic 
compounds. It should be noted that at 60 days, the removal efficiency of filters with alternative materials (bamboo, foam and luffa) reached around $80 \%$, while the filter containing gravel had a BOD removal efficiency of $65 \%$.
Graphs depicting BOD, total nitrogen and total phosphorus removal efficiency are shown in Figures 2A, 2B and 2C, respectively.

(A)

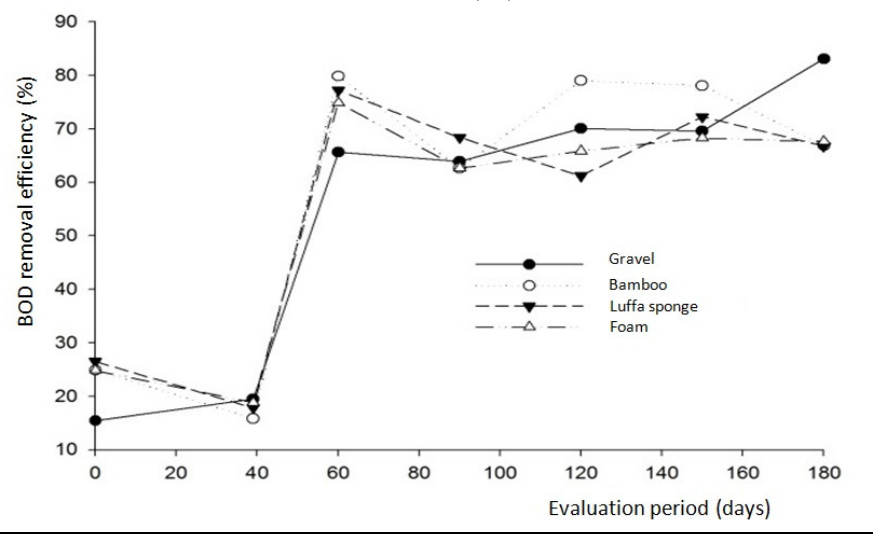

(B)

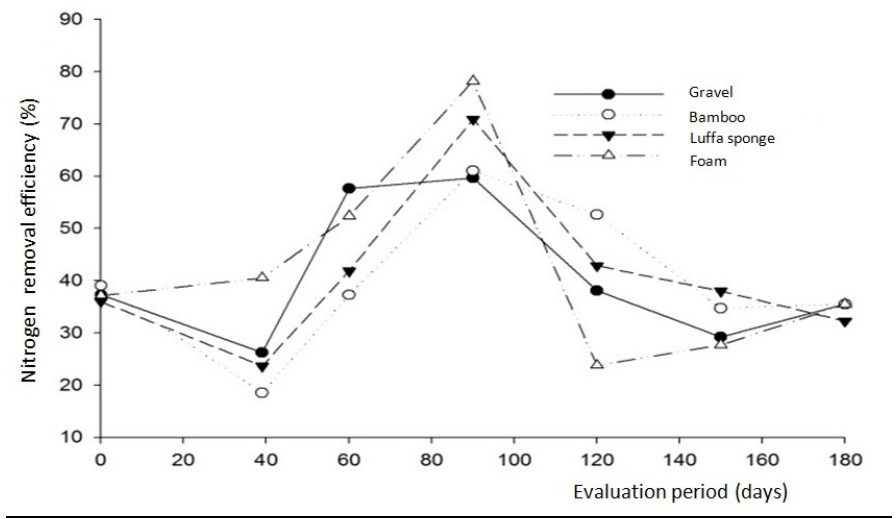

(C)

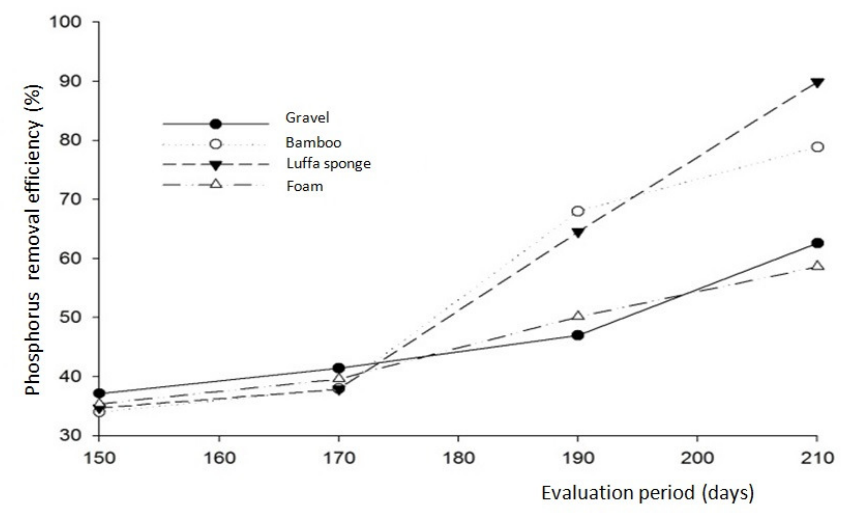

Figure 2. Change in the biochemical oxygen demand (BOD) (A), total nitrogen (B), and total phosphorus (C) removal efficiencies according to the different evaluation periods.

At 120 and 150 days of operation (4 and 5 months, respectively), the bamboo filter presented the highest efficiencies (around 80\%) among the evaluated materials.

Up to the end of the evaluation period (180 days), there were small oscillations in the efficiency, which may be associated with the different organic loads of inputs, besides the variation of the environmental temperature during the period evaluated. In general, all filters had reasonable removal efficiency, with filters containing bamboo, luffa and foam reaching around 65\% of BOD removal efficiency, and filters containing gravel, $80 \%$. 
The mean BOD values found in this study are close to those reported by Campos et al. (2005), namely $75 \%$ efficiency in the removal of BOD from wastewater from swine farms. However, in that study, the authors used a system consisting of an acidification and equalization tank (AET), upflow anaerobic sludge blanket (UASB) and factored aerated lagoon (FAL), substantially more complex than the system used in this study. Tonetti et al. (2012) obtained an average removal of $68 \pm 9 \%$ of BOD during a 6-month experimental period with anaerobic filters containing bamboo rings as support material and a 9-h HDT in the treatment of domestic sewage.

As shown in Figure 2b, initially filters had a total $\mathrm{N}$ removal efficiency of about 37 to $40 \%$. At 40 days of operation, there was a decrease to $20 \%$, except with filters containing foam which maintained efficiency at around 40\%. Between 60 and 100 days of operation, the filters presented the greatest efficiencies throughout the evaluated period. Filters containing gravel and bamboo rings as media support reached maximum efficiencies of around $60 \%$, while filters containing luffa and foam reached efficiencies of around 80 and $70 \%$, respectively. It is considered that, during this period, the highest removal efficiencies of total $\mathrm{N}$ are related to biofilm evolution, increased biochemical activity due to high temperatures in this period (Figure 1) and nitrogen incorporation into the biomass itself.

The high efficiency of total $\mathrm{N}$ removal by foam and luffa could be related to higher biofilm adaptation and formation, approaching the efficiency obtained by Abreu e Zaiat (2008), who found an average efficiency of ammoniacal $\mathrm{N}$ removal of $85 \%$ when evaluating a foam system in domestic wastewater treatment. However, the authors used a preliminary and primary treatment before conducting the effluent to the anaerobic filter.

Total $\mathrm{N}$ removal efficiency obtained in this study was higher than that obtained by Tonetti et al. (2012), who evaluated the post-treatment of effluents from anaerobic filters with bamboo fillings and found only $16 \%$ efficiency. However, in the reported study, the HDT was $3 \mathrm{~h}$, a value different from that used in this research $(12 \mathrm{~h})$. Thus, the longer detention time and, consequently, longer contact time of nutrients with the biofilm may have produced greater total $\mathrm{N}$ removal efficiency.

As shown in Figure 2c, all filters had low total $\mathrm{P}$ removal efficiency (around 38\%) from 150 to 170 days of evaluation. The lower efficiencies obtained corroborate with Chernicharo (2007), who state that anaerobic filters have a disadvantage with regard to the low efficiency of $\mathrm{P}$ removal, requiring the application of a post-treatment.

As the phosphorus removal efficiency was low in the initial phases, it is recommended to use the effluent from the studied filters in fertigation systems, since the turbidity (Table 3 ), variable related to the presence of suspended solids, in high concentrations, would contribute to the clogging in the irrigation systems, were retained by the filters.

From 170 days, higher phosphorus removal efficiencies were obtained, reaching maximum values at 210 days of evaluation. This finding may be an indication that longer adaptation periods are necessary for anaerobic filters to have a good efficiency in the removal of total P.

It should be noted that, at the end of the evaluation period, filters containing bamboo and luffa showed a high efficiency, reaching maximum removal values of $80 \%$ and $90 \%$, respectively. Although the filters containing gravel and foam also showed higher removal efficiency of $\mathrm{P}$ in relation to the initial period of evaluation, this increase was more discrete when compared to other filters (bamboo and luffa), with efficiency in the final evaluation period of around $60 \%$. Tonetti et al. (2012) found a total P removal efficiency of $19 \%$ in a study of post-treatment of effluent from anaerobic filters with a HDT of $3 \mathrm{~h}$. However, the HDT used by the authors was lower than that used in this study (12 h).

The high efficiency of phosphorus removal can be attributed to the incorporation of phosphorus into the biomass, as observed by Souza et al. (2010), which, under certain environmental conditions, can accumulate excess phosphorus levels. In addition, the increase in phosphorus removal efficiency can be attributed to the higher $\mathrm{pH}$ values observed in the filter affluent (Table 2), which probably favored the precipitation of phosphate salts on the media support, as demonstrated by Duda et al. (2011).

According to the results of this study, it can be concluded that, among the alternative media investigated, bamboo presented removal efficiency of the evaluated attributes that was similar and, in most cases, superior to gravel.

From 60 to 180 days of filter operation, luffa maintained high turbidity and total solids removal, with the greatest decrease among the evaluated materials at 240 days of operation.

After 2 months of filter operation, the alternative media support exhibited BOD and total $\mathrm{N}$ removal similar to gravel. 
At the end of the evaluation period, the filters containing luffa and bamboo showed the highest phosphorus removal.

RESUMO: Pesquisas utilizando filtros anaeróbios com materiais alternativos à brita tornam-se fundamentais, principalmente se forem de baixo custo, acessíveis e possibilitem elevada eficiência no tratamento de águas residuárias de suinocultura. Objetivou-se avaliar a eficiência de filtros anaeróbios com diferentes tipos de meio suporte, alternativos à brita, no tratamento de águas residuárias da suinocultura. $\mathrm{O}$ experimento foi realizado em delineamento inteiramente ao acaso, sendo os tratamentos compostos por filtros anaeróbios com quatro diferentes meios suportes (brita, bambu, bucha vegetal e espuma), três repetições em esquema de medidas repetidas no tempo, $(0,60,120,180$ e 240 dias pós-estabelecimento dos filtros). Para a determinação da eficiência de remoção nos filtros, análises de turbidez, sólidos totais, Demanda Bioquímica de Oxigênio (DBO), N-total e P-total foram realizadas no afluente e no efluente aos filtros. Dentre os meios suportes alternativos, o bambu apresentou eficiências de remoção dos atributos avaliados semelhantes e, na maioria das vezes, superiores à brita. Dos 60 aos 180 dias de operação dos filtros, a bucha vegetal manteve-se com elevadas remoções de turbidez e sólidos totais, tendo o maior decréscimo, aos 240 dias de operação. Após 2 meses de operação dos filtros, os meios suportes alternativos apresentaram remoções de DBO e N-total semelhantes à brita. Aos 240 dias de operação, os filtros contendo bucha vegetal e bambu apresentaram as maiores remoções de P-total.

PALAVRAS-CHAVE: Tratamento secundário. Resíduos líquidos. Eficiência de remoção.

\section{REFERENCES}

ABREU, S. B.; ZAIAT, M. Desempenho de reator anaeróbio-aeróbio de leito fixo no tratamento de esgoto sanitário. Revista de Engenharia Sanitária e Ambiental, Rio de Janeiro, v. 13, n. 2, p. 181-188, 2008. https://doi.org/10.1590/S1413-41522008000200008

APPELS, L.; BAEYENS, J.; DEGRÈVE, J.; DEWIL, R. Principles and potential of the anaerobic digestion of wasteactivated sludge. Energy and Combustion, London, v. 34, p. 755-781, Aug. 2008.

https://doi.org/10.1016/j.pecs.2008.06.002

ARAÚJO, G. M.; LIMA NETO, I. E.; ARAÚJO, A. L. C.; SILVA, M. E. R. Avaliação experimental e modelagem matemática de filtros anaeróbios como alternativa de baixo custo para remoção de algas de efluentes de lagoas de estabilização. Engenharia Sanitária e Ambiental, Rio de Janeiro, v. 21, n. 4, p. 687696, 2016. https://doi.org/10.1590/s1413-41522016134641

CAMPOS, C. M. M.; CARMO, F. D.; BOTELHO, C. G.; COSTA, C. C. D. Desenvolvimento e operação de reator anaeróbio de manta de lodo (UASB) no tratamento dos efluentes da suinocultura em escala laboratorial. Ciência e Agrotecnologia, Lavras, v. 30, n. 1, p. 140-147, 2008.

CAMPOS, C. M. M.; MOCHIZUKI, E. T.; DAMASCENO, L. H. S.; BOTELHO, C. G. Avaliação do potencial de produção de biogás e da eficiência de tratamento do reator anaeróbio de manta de lodo (UASB) alimentado com dejetos de suínos. Ciência e Agrotecnologia, Lavras, v. 29, n. 4, p. 848-856, jul./ago. 2005.

CHANAKYA, H. N.; KHUNTIA, H. K. Treatment of gray water using anaerobic biofilms created on synthetic and natural fibers. Process Safety and Environmental Protection, v. 92, n. 2, p. 186-192, March 2014. https://doi.org/10.1016/j.psep.2012.12.004

CHERNICHARO, C.A.L. Reatores anaeróbios: princípios do tratamento biológico em águas residuárias. Vol 5. Belo Horizonte: Segrac, 1997. 246 p.

CHERNICHARO, C.A.L. Reatores anaeróbios: princípios do tratamento biológico em águas residuárias. 2.ed. Belo Horizonte: DESA/UFMG, 2007. 359 p. 
DUDA, R. M.; OLIVEIRA, R. A. Reatores anaeróbios operados em batelada sequencial, seguidos de lagoas de polimento, para o tratamento de águas residuárias de suinocultura. Parte I: produção de metano e remoção de DQO e de sólidos suspensos. Engenharia Agrícola, Jaboticabal, v. 29, n. 1, p. 122-134, 2009. https://doi.org/10.1590/S0100-69162009000100013

FERNANDES, W. V.; ATHAYDE, G. B. J.; BATISTA, M. M.; ANJOS JUNIOR, R. H. Avaliação da remoção de matéria orgânica de efluente de tanque séptico utilizando filtro anaeróbico preenchido com Luffa cylindrica como meio de suporte. Revista Eletrônica de Gestão e Tecnologias Ambientais, v. 3, n. 1, p. 1-13, 2015. https://doi.org/10.17565/gesta.v3i1.12995

FIA, F. R. L.; MATOS, A. T.; BORGES, A. C.; MOREIRA, D. A.; FIA, R.; EUSTÁQUIO JÚNIOR, V. Remoção de compostos fenólicos em reatores anaeróbios de leito fixo com diferentes materiais suporte.

Revista Brasileira de Engenharia Agrícola e Ambiental, Campina Grande, v.14, n.10, p.1079-1086, 2010. https://doi.org/10.1590/S1415-43662010001000009

KIM, W.; HWANG, K.; SHIN, S. G.; LEE, S. HWANG, S. Effect of high temperature on bacterial community dynamics in anaerobic acidogenesis using mesophilic sludge inoculum. Bioresource Technology, v. 1, n. 1, p. 17-22, 2009. https://doi.org/10.1016/j.biortech.2009.03.029

MATOS, A. T.; FREITAS, W. S.; LO MONACO, P.A.V. Eficiência de alagados construídos na remoção de poluentes de águas residuárias da suinocultura. Ambi-Água, Taubaté, v.5, n.2, p.119-132, 2010.

MATOS, A. T.; FREITAS, W. S.; LO MONACO, P. A. V. Capacidade extratora de diferentes espécies vegetais cultivadas em sistemas alagados utilizados no tratamento de águas residuárias da suinocultura. AmbiÁgua, Taubaté, v. 4, n. 2, p. 31-45, 2009.

MATOS, A. T. Manual de análise de resíduos sólidos e águas residuárias. $1^{\mathrm{a}}$ ed. Viçosa: Editora UFV, 2015. 149p.

MIDDLEBROOKS, E. J. Review of rock filters for the upgrade of lagoon effluents. Journal Water Pollution Control Federation, v. 60, n. 9, p. 1.657-1.662, 1988.

SOUZA, R. C. DE; ISOLDI, L. A.; OLIZ, C. M. Tratamento de Esgoto Doméstico por Filtro Anaeróbio com Recheio de Bambu. Revista Vetor, Rio Grande, v. 20, n. 2, p. 5-19, 2010.

TONETTI, A. L.; CORAUCCI FILHO, B.; STEFANUTTI, R. Pós-tratamento de efluente de filtros anaeróbios operados com baixo tempo de detenção hidráulica por escoamento superficial no solo. Engenharia Sanitária e Ambiental, Rio de Janeiro, v.17, n.1, p.7-12, 2012. https://doi.org/10.1590/S1413-41522012000100004

TONETTI, A. L.; FILHO, B. C.; GUIMARÃES, J. R.; CRUZ, L. M. O.; NAKAMURA, M. S; Avaliação de partida de filtros anaeróbios tendo bambu como material de recheio. Engenharia Sanitária e Ambiental, Rio de Janeiro, v. 16, n.1, p. 11-16, 2011. https://doi.org/10.1590/S1413-41522011000100004

ZAIAT, M.; CABRAL, A. K. A.; FORESTI, E. Reator Anaeróbio Horizontal de Leito Fixo Para Tratamento de Águas Residuárias: Concepção e Avaliação Preliminar de Desempenho. Revista Brasileira de Engenharia, Caderno de Engenharia Química, São Carlos, v. 11, n. 2, p. 33-42, 1994. 